\title{
COMBINATION OF SAMBILOTO (ANDROGRAPHIS PANICULATA (BURM.F.) NEES) EXTRACT AND SPIRULINA (ARTHROSPIRA PLATENSIS GOMONT) TO PREVENT ANEMIA IN MICE INFECTED WITH PLASMODIUM BERGHEI ANKA
}

\author{
KUSMARDI KUSMARDI ${ }^{1}$, BERNA ELYA ${ }^{2}$, TRI WAHYUNI ${ }^{3}$, RAFIKA INDAH PARAMITA**
}

${ }^{1}$ Department of Anatomical Pathology, Faculty of Medicine, Universitas Indonesia, Jakarta, Indonesia. ${ }^{2}$ Department of Phytochemistry and Pharmacognosy, Laboratory of Phytochemistry and Pharmacognosy, Faculty of Pharmacy, Universitas Indonesia, Depok, Indonesia. ${ }^{3}$ National Institute of Health Research and Development, Ministry of Health of Indonesia, Jakarta, Indonesia. ${ }^{4}$ Department of Medical Chemistry, Faculty of Medicine, Universitas Indonesia, Jakarta, Indonesia. Email: fika.paramita@gmail.com

Received: 13 July 2017, Revised and Accepted: 06 September 2017

\section{ABSTRACT}

Objective: Anemia in acute malaria occurs because there is massive lysis of erythrocytes as a result of an increase in parasitemia or use of drugs that may induce hemolysis. In this research, it was tested the effect of administration of a combination of sambiloto (Andrographis paniculata Nees) extract and spirulina (Arthrospira platensis Gomont). This combination is aimed to obtain antiparasite activity of sambiloto and increasing of hemoglobin $(\mathrm{Hb})$ from spirulina.

Methods: This research was conducted with a completely randomized design using 75 mice of Swiss Webster strain. Test groups were consisted of AP, $\mathrm{AP}+\mathrm{ES}, \mathrm{AP}+\mathrm{PS}$, carboxymethyl cellulose, and dihydroartemisinin-piperaquine. All mice were infected with Plasmodium berghei on the day 0 . The test material extracts were given 3 days before infection (H-3) and every day for 28 days after infection. Parasitemia data were taken on day $3,7,10,15$, 21, and 28, while the data for erythrocyte count and Hb level were taken on day 3, 10, and 21. Data processing was conducted using one-way ANOVA, followed by post hoc test.

Results: This study showed that combination of sambiloto extract and spirulina powder (AP+PS) gave a significant difference result in suppressing the percentage of parasitemia $(\mathrm{p}=0.02)$, increasing the erythrocyte count ( $\mathrm{p}=0.03)$, and $\mathrm{Hb}$ level $(\mathrm{p}=0.01)$ at the $15^{\text {th }}$ day, compared to the group given only sambiloto (AP).

Conclusion: Combination of spirulina powder and sambiloto extract will decrease parasitemia and increase the number of erythrocyte and $\mathrm{Hb}$ in mice that infected by $P$. berghei.

Keywords: Antimalaria, Andrographis paniculata Nees, Arthrospira platensis Gomont, Hematology.

(c) 2017 The Authors. Published by Innovare Academic Sciences Pvt Ltd. This is an open access article under the CC BY license (http://creativecommons. org/licenses/by/4. 0/) DOI: http://dx.doi.org/10.22159/ajpcr.2017.v10i12.21231

\section{INTRODUCTION}

Malarial management is still a priority in the national level of public health infectious disease control. This is due to the wide endemicity of malaria in some regions, especially in the tropical countries. According to the National Report of Basic Health Research 2013, 5 provinces with the highest incidence and prevalence are all located in the East of Indonesia. From 33 provinces in Indonesia, 15 provinces have higher malarial prevalence, above the average national score [1].

It has been showed that, in some endemic areas, the local community may use natural remedies to cure malaria. The proportion of typical Indonesian households employing traditional health service is about $30.4 \%$. From the $30.4 \%$ employing this service, $49 \%$ uses herbal remedies. This indicates that drugs from natural sources, particularly herbal plants, have their roles in the implementation of community health practices [1-4].

Some herbal plants are reported to show antiplasmodium activity, one of which is sambiloto (Andrographis paniculata L.) [5,6]. Administration of sambiloto herbal extract to Balb C mice led to the increase of survival and general conditions of the mice during infection but did not result in the increase of erythrocyte count during the process of infection of Plasmodium berghei Anka [7]. Use of micronutrients with antioxidant activity in drug therapy on antimalarial mice gives better result [8]. C-phycocyanin from Spirulina platensis gives protection against oxidative damage to DNA plasmid protein and erythrocyte membrane. Administration of spirulina powder in a dosage of 250 and $500 \mathrm{mg} / \mathrm{kg}$ body weight for 14 days to white mice induced with cyclophosphamide can prevent decrease in hemoglobin ( $\mathrm{Hb}$ ) level and erythrocyte and leukocyte counts [9]

In this research, it is expected that administration of a combination of sambiloto dan spirulina can lower parasitemia, increase survival, and increase erythrocyte count and $\mathrm{Hb}$ level in mice infected with $P$. berghei.

\section{METHODS}

The plant of Sambiloto was identified by Herbarium Bogoriense, Pusat Penelitian Biologi-LIPI Bogor as A. paniculata (Burm.f.) Nees, familia Acanthaceae. Spirulina algae were identified by Pusat Penelitian Limnologi LIPI Bogor as S. platensis.

This research has gained Ethical Clearance from the Ethical Commission for Health Research, Faculty of Medicine, University of Indonesia No. 161/UN2.F1/ETIK/2015, on March 3, 2015. Sambiloto in the form of powder was obtained from the Research Institute for Spices and Medicinal Plants (Balittro, Bogor). A. paniculata (Burm.f.) Nees extract was prepared by maceration with $70 \%$ ethanol, and then, concentrated and dried. Spirulina used in this research is in powder form produced by PT. Trans Pangan Spirulindo cultivated in Teluk Awur, Jepara, Central Java, no cat. SB01/2014. The Arthrospira platensis extract was prepared by maceration with $80 \%$ ethanol at $60^{\circ} \mathrm{C}[10]$.

After extraction process was carried out, then we did phytochemistry test to define the substance in each sample. The result was showed in 
Table 1: Phytochemistry of sambiloto extract and spirulina extract and powder

\begin{tabular}{llll}
\hline Substance & $\begin{array}{l}\text { Sambiloto } \\
\text { extract }\end{array}$ & $\begin{array}{l}\text { Spirulina } \\
\text { extract }\end{array}$ & Spirulina powder \\
\hline Alkaloid & - & - & - \\
Flavonoid & + & + & + \\
Tannin & - & - & - \\
Steroid & + & - & + \\
Saponin & + & + & + \\
Hydroquinone & - & - & - \\
Triterpenoid & - & + & - \\
\hline
\end{tabular}

Table 2: Active ingredients content of sambiloto extract and spirulina extract and powder

\begin{tabular}{llll}
\hline $\begin{array}{l}\text { Test } \\
\text { sample }\end{array}$ & $\begin{array}{l}\text { Active } \\
\text { ingredient }\end{array}$ & Content & Test method \\
\hline $\begin{array}{l}\text { Sambiloto } \\
\text { extract }\end{array}$ & Andrographolide & $8.30 \% \mathrm{w} / \mathrm{w}$ & HPLC \\
$\begin{array}{l}\text { Spirulina } \\
\text { extract }\end{array}$ & Flavonoid & $0.64 \% \mathrm{w} / \mathrm{w}$ & Spectrophotometry \\
$\begin{array}{l}\text { Spirulina } \\
\text { powder }\end{array}$ & Flavonoid & $0.10 \% \mathrm{w} / \mathrm{w}$ & Spectrophotometry \\
\hline
\end{tabular}

HPLC: High-performance liquid chromatography

Table 1. We also identified active ingredient of the sample using HPLC and spectrophotometry methods. The result was showed in Table 2.

Mice used are of Swiss Webster strain, 24-28 g, 8-10 weeks old, male. The mice were given anthelmintic since they were 6-week-old. Afterward, the mice were grouped and quarantined for at least 7 days. The mice were kept in fiberglass cages with stainless steel lids and fed with pellet and sufficient water. The cages were $425 \mathrm{~mm} \times 2260 \mathrm{~mm} \times 185 \mathrm{~mm}$ size and made of polycarbonate. The animals were placed in the cages in a room with good lighting and air circulation at room temperature with $26-27 \%$ humidity.

The animals were divided into five groups: AP (the mice were infected with $P$. berghei and accepted sambiloto extract), AP+ES (the mice were infected with $P$. berghei and accepted combination of sambiloto and spirulina extracts), AP+PS (the mice were infected with $P$. berghei and accepted combination of sambiloto extract and spirulina powder), dihydroartemisinin-piperaquine (DHP) (the mice were infected with P. berghei and accepted DHP), and control group (the mice were infected with $P$. berghei and accepted carboxymethyl cellulose).

This experiment used 2 treatments series. In the first series of treatment, the mice were divided into 5 groups with 6 mice for each group and used to obtain the parasitemia and survival data. The test materials were given 3 days before induction to the day of induction (D-3 to D0). The mice were infected with P. berghei on D0. Blood smear was prepared to determine the parasitemia on day $3,10,15,21$, and 28; mice survival rate was observed during the period of infection. In the second series of treatment, the mice were divided into 5 groups with 3 mice for each group and used to obtain the erythrocyte count and $\mathrm{Hb}$ level at 3 points of time (D3, 10, 21).

P. berghei was given to 5 donor mice, $0.1 \mathrm{ml}$ parasite stock suspension each, intraperitoneally (i.p). The mice were sacrificed, the blood was taken, diluted, and infected to experimental animals $0.1 \mathrm{ml}$ intraperitoneally such that the animals accepted $1.3 \times 10^{5}$ parasiteinfected erythrocytes per milliliter [11].

The dosage of sambiloto extract was $200 \mathrm{mg} / \mathrm{kg}$ body weight, the dosage that has provided inhibition to the activity of $P$. berghei in mice and is a sub-chronically safe dosage $[12,13]$. The dosage of spirulina powder used was $130 \mathrm{mg} / \mathrm{kg}$ body weight as determined by the 28-day sub-chronic toxicity test on mice, where $130 \mathrm{mg} / \mathrm{kg}$ body weight was a safe dose, while the dosage of spirulina extract used was the dosage of spirulina powder multiplied by the percent yield of the ethanol extract. DHP tablet was given $195 \mathrm{mg} / \mathrm{kg}$ body weight (containing $15.5 \mathrm{mg}$ dihydroartemisinin and $124 \mathrm{mg}$ piperaquine) administered per oral to the mice using feeding tube, for 4 consecutive days [14]. Combination of extracts was given per oral using feeding tube 3 days before the infection (D-3), the animals were then infected with P. berghei (D0) and were given the extracts again until the last day of experiment.

In the second series, the test materials were given 3 days before the induction until the day of induction. The mice were infected with P. berghei on D0. The test materials administration was continued until D21. Blood sampling for hematology determination was conducted by sacrificing 3 mice in every group on D3, 10, and 21 . The mice were anesthetized intraperitoneally with ketamine $75-100 \mathrm{mg} / \mathrm{kg}$ and xylazine $10 \mathrm{mg} / \mathrm{kg}$, using 23-26 G × 13-25 m syringe and needle, and then, the blood from vena orbitalis was taken $0.5 \mathrm{ml}$ and added with ethylenediaminetetraacetic acid (EDTA) as anticoagulant, for hematology analysis [15].

A thin blood smear was prepared. After the smear dried, it was then fixed with methanol and dyed with $10 \%$ Giemsa solution. Parasitemia was counted using a microscope with $\times 100$ magnification and addition of immersion oil. Parasitemia indicates the parasite-infected red blood cell (iRBC) density in every 1000 RBCs. The formulation to calculate the percentage of RBCs infected with malarial parasite in the thin blood smear is as follows:

Parasitemia $=(\Sigma$ parasite-infected erythrocyte $/ \Sigma$ total erythrocyte $) \times$ $100 \%$

Hematology analysis was conducted to $1.0 \mathrm{ml}$ blood added with $45 \mu \mathrm{l}$ $10 \%$ EDTA using a hematology analyzer, in which the main parameters analyzed were total erythrocyte count and $\mathrm{Hb}$ level. The data for parasitemia, survival, erythrocyte count, and $\mathrm{Hb}$ level were analyzed using one-way ANOVA test, followed by a least significant difference (LSD) test.

\section{RESULTS}

Phytochemistry analysis of sambiloto extract and spirulina extract and powder were conducted by color visualization method. Spirulina extract and powder each contains flavonoid and so does sambiloto extract.

Flavonoid determination in spirulina powder and extract using spectrophotometer demonstrated that flavonoid in the spirulina extract was higher than in the powder form. However, the spirulina powder used in this research is 5 times weight of that of spirulina extract, and this means that every experimental animal was given spirulina extract or powder with approximately the same flavonoid content.

All groups of treatments demonstrated significant parasitemia difference compared to CMC. Combination of sambiloto and spirulina is able to accelerate parasite elimination than sambiloto alone. The combination of sambiloto and spirulina extract (AP+ES) did not show significance $(p=0.06)$ to sambiloto (AP) alone.

In the DHP group, on D3, the erythrocyte count decreased significantly compared to AP group ( $p=0.01)$ and AP+ES group $(p=0.015)$. On D10, there was a decrease in the erythrocyte count and $\mathrm{Hb}$ level, especially in the CMC and AP groups. On D21 after infection, all groups of treatments had been able to restore the erythrocyte count to the normal level.

\section{DISCUSSION}

Some herbal plants are reported to show antiplasmodium activity, and sambiloto (A. paniculata (Burm.f.) Nees) is one of these herbals. Sambiloto extract has antimalarial falciparum effect in vitro, and this effect reaches the maximum level when the dosage is $200 \mu \mathrm{g} / \mathrm{ml}$. The antimalarial effect of sambiloto extract may be used in monotherapy or 
in combination with chloroquine and artemisinin [6]. A clinical study showed that the antimalarial efficacy of sambiloto $250 \mathrm{mg}$, sambiloto $500 \mathrm{mg}$, and the combination of sambiloto $250 \mathrm{mg}$ with chloroquine and sambiloto $250 \mathrm{mg}$ with artesunate are $90.0 ; 90.5 ; 90.2$; and $95.2 \%$ ( $p>0.3$ ), respectively [3]. Administration of sambiloto herbal extract to Balb C mice resulted in an increase in survival and general conditions of the mice during infection but did not have any effect in the increase of erythrocyte count during the process of infection of P. berghei Anka [7].

Use of micronutrient with antioxidant activity in drug therapy on antimalarial mice gives better result [8]. Antioxidants work by neutralizing free radicals produced by the parasites and the immune system, inhibiting the peroxidation of lipid membrane, thereby preventing the iRBC from lysis. Antioxidants, therefore, may lower the risk of anemia in malaria [16]. C-phycocyanin of S. platensis provides protection against the oxidative damage to the DNA plasmid protein and erythrocyte membrane. Administration of spirulina powder in a dosage of 250 and $500 \mathrm{mg} / \mathrm{kg}$ body weight for 14 days to white mice induced with cyclophosphamide can prevent a decrease in Hb level and erythrocyte and leukocyte counts [9].

The testgroups consisted of AP (sambiloto extract), AP+ES (combination of sambiloto and spirulina extract), $\mathrm{AP}+\mathrm{PS}$ (combination of sambiloto and spirulina powder), control (CMC), and DHP. All mice were infected with $P$. berghei on day 0 . The extracts of the test materials were given 3 days before infection ( $\mathrm{H}-3)$, and then, every day with 24 hrs interval, for 28 days after infection. The data for parasitemia (Fig. 1), erythrocyte count (Fig. 2), and Hb level (Fig. 3) of spleen cells were obtained on D3, D10, and D21, respectively. Data processing was conducted using oneway ANOVA, followed by LSD test.

Dosage calculation was based on the sub-chronically safe dosage on mice, which simultaneously provides the antimalarial effect. In this research, the administration of sambiloto extract was conducted for 28 days on the consideration that if sambiloto extract was given for only 4 days (D0-D3), like in the conventional antimalarial administration, the parasite would increase again after the termination of sambiloto extract administration. This is due to the remaining parasites alive will be able to divide again. In the meantime, the active ingredients would have been excreted out of the body. Sambiloto extract $231.48 \mathrm{mg} / \mathrm{kg}$ body weight provides $70 \%$ inhibition to the P. berghei growth on the 4-day suppressive test of blood schizontocidal action [12]. Use of sambiloto extract up to $300 \mathrm{mg} / \mathrm{kg}$ body weight is safe for 28 days of administration [13]

In this research, it was used sambiloto extract dosage of $200 \mathrm{mg} / \mathrm{kg}$ body weight or $5 \mathrm{mg} / 25 \mathrm{~g}$ body weight. As for spirulina powder, the dosage was determined based on the research of Murtini et al., who reported that spirulina powder consumption of $1 \mathrm{~g} / 70 \mathrm{~kg}$ human body weight or $130 \mathrm{mg} / \mathrm{kg}$ mouse body weight for 28 days does not result in microscopic organ abnormalities. In this case, the dosage for spirulina extract was determined based on the yield of spirulina ethanol extract, i.e., $20 \%$ of the spirulina powder weight [14].

Dosage selection in this research was determined after previously conducting dosage optimization (Fig. 4). Sambiloto dosage of 462 and $925 \mathrm{mg} / \mathrm{kg}$ body weight until D4 can provide 89.84 and $72.75 \%$ parasite inhibition, respectively [12]. Despite this, those dosages are not suitable for a long-term administration because some animals in every group did not survive until the end of the research period. This is probably because the sambiloto extract contains saponin in which the increase in saponin concentration in line with the increase in the dosage of sambiloto extract may cause hemolysis. Saponin induces hemolysis by increasing the water transport in the aquaporin canal [17]. The lysed of infected erythrocytes can increase the distribution of parasite which will result in the increase in the degree of parasitemia [16]. Bukoye and Musbau also demonstrated that sambiloto extract administration of $1000 \mathrm{mg} / \mathrm{kg}$ body weight every day caused death of normal mice on D32. Hematology analysis showed an increase in erythrocyte count, decrease in $\mathrm{Hb}$ level, and increase in erythrocyte sedimentation rate [18].
Group AP, AP+ES, AP+PS, and DHP showed 100\% survival, which means that all experimental animals in the four groups are all alive until the end of the period of research. The antimalarial mechanism of a herbal medicine is suggested through the inhibition of parasite growth or by indirectly kill the parasites [19]. In the CMC group, death was found gradually from the D7 to D20 after infection. On D21, experimental animals in the CMC group were all dead.

On D3, there is a significant difference $(p=0.02)$ on the percentage of parasitemia between all groups of treatments and the DHP group. This indicates that DHP has already showed schizontocidal effect. Day 10 parasitemia data analyzed with Kruskal-Wallis test showed a significant difference $(\mathrm{p}=0.00)$, which means that there is a significant difference among the groups. A significant difference of parasitemia percentage occurs among all groups of treatments and between the DHP and the CMC groups. Significance $(p=0.032)$ also occurs to the groups of AP (sambiloto) and AP+PS (combination of sambiloto and spirulina powder). These data indicate that combination of spirulina and sambiloto is able to accelerate parasite elimination compared to sambiloto alone, whereas the combination of sambiloto and spirulina extract $(\mathrm{AP}+\mathrm{ES})$ did not show significance $(\mathrm{p}=0.06)$ to sambiloto (AP). Different results demonstrated by spirulina extract and powder probably related to the water-soluble compounds with antiparasite activity present in spirulina powder but not in the extract.

C-phycocyanin in A. platensis is a naturally occurring or primary antioxidant belongs to the group of flavonoid and water soluble. Chemical structure of c-phycocyanin can stabilize peroxide radicals by adding one hydrogen atom to the radicals. The capability to inhibit hydroxyl radicals depends on the phycocyanin concentration [9].

The percentage of parasitemia in CMC group increased steadily up to $>80 \%$ that it caused death to all animals in this group on D20. Tripathy et al., in their study, showed that there was an increase in nicotinamide adenine dinucleotide phosphate (NADPH) oxidase enzyme and nitrogen oxide (NO) in the serum of the experimental mice during the first 10 days of infection. NADPH oxidase provides electron from NADPH in the internal cytoplasm membrane to extracellular to produce superoxide radicals $\left(\mathrm{O}_{2}^{-}\right)$. NO reacts with $\mathrm{O}_{2}^{-}$to produce peroxynitrite that can interact with various biological molecules and has destructive power [15]

On D15 after infection, parasitemia dropped (Fig. 1). All groups receiving herbal treatments showed parasitemia approaching $0 \%$. On D21 after infection, all groups of treatments, excluding CMC, had been able to eliminate parasites ( $0 \%$ parasitemia). This indicates that all groups of herbal treatments have shown recovery from infection. Parasite elimination on D15 is considered as a result of andrographolide action in inhibiting the distribution of parasites in the ring phase, which is probably related to its function as a "transcription blocker," i.e., inhibit the synthesis of protein and nucleic acid [18]. In general, the antimalarial mechanism of a herbal medicine is through the inhibition of parasites growth or by indirectly kill the parasites. As cited in Percário et al., 2012, "unlike the typical mechanism of antimalarial drugs, which is through the induction of oxidative stress, antimalarial substances from natural sources act by modulating the immune system which will kill the parasites indirectly" [19]. Therefore, the antiparasite ingredients of herbal medicines act by minimizing the change in the host's redox equilibrium.

In the DHP group, on D3, the erythrocyte count decreased significantly compared to AP group ( $\mathrm{p}=0.01$ ) and AP+ES group ( $\mathrm{p}=0.015)$ (Fig. 2). This is as a result of piperaquine content of DHP, which is a chloroquine derivative. Chloroquine has a function of preventing hemozoin to be produced and causing free heme accumulation. Free heme is free radical generator which may cause serious damage to the host and parasites. This group of heme contains $\mathrm{Fe}^{2+}$ atom which catalyzes Fenton and Haber-Weiss reaction releasing free radicals [19]. Free radicals cause lipid peroxidation in the membrane of the RBCs and shorten the age of 


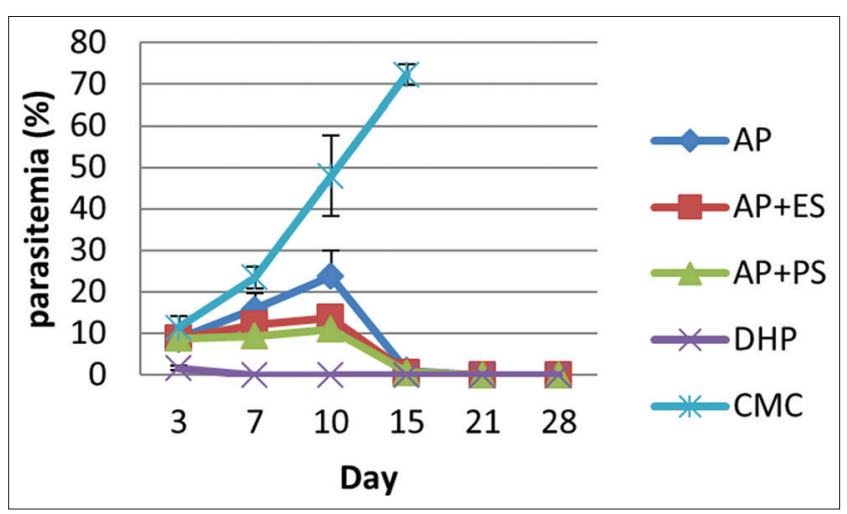

Fig. 1: Percentage of parasitemia. Group: $A P=S a m b i l o t o$ $200 \mathrm{mg} / \mathrm{kg}$ body weight; AP+ES=Sambiloto $200 \mathrm{mg} / \mathrm{kg}$ body weight+spirulina extract $26 \mathrm{mg} / \mathrm{kg}$ body weight; $\mathrm{AP}+\mathrm{PS}=$ Sambiloto $200 \mathrm{mg} / \mathrm{kg}$ body weight+spirulina powder $130 \mathrm{mg} / \mathrm{kg}$ body weight; DHP=Dihydroartemisinin-piperaquine (dihydroartemisinin $15.6 \mathrm{mg}$; piperaquine $124.5 \mathrm{mg} / \mathrm{kg}$ body weight); $\mathrm{CMC}=$ Carboxymethyl cellulose $0.5 \%$

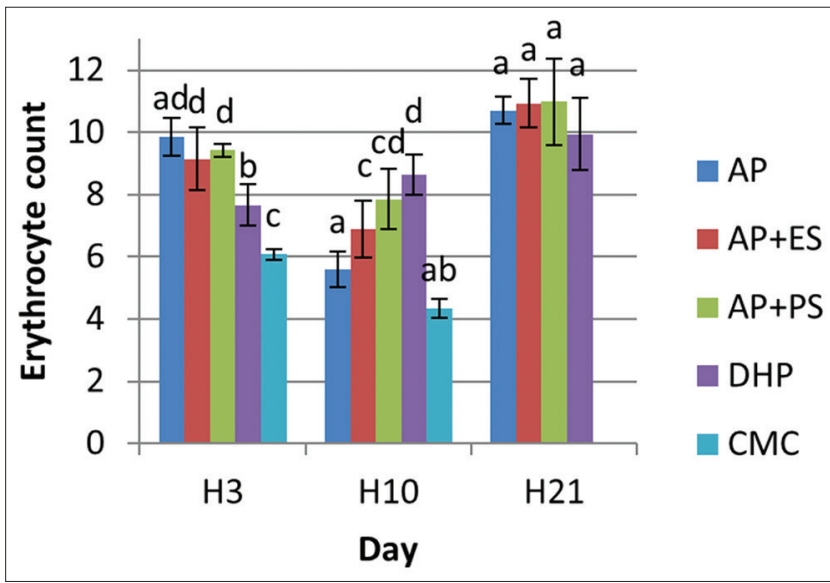

Fig. 2: Erythrocyte count $(\times 106 / \mathrm{ml})$ Group: $A P=S a m b i l o t o$ $200 \mathrm{mg} / \mathrm{kg}$ body weight; AP+ES=Sambiloto $200 \mathrm{mg} / \mathrm{kg}$ body weight+spirulina extract $26 \mathrm{mg} / \mathrm{kg}$ body weight; AP+PS=Sambiloto $200 \mathrm{mg} / \mathrm{kg}$ body weight+spirulina powder $130 \mathrm{mg} / \mathrm{kg}$ body weight; DHP=Dihydroartemisininpiperaquine (dihydroartemisinin 15.6 mg; piperaquine 124.5 $\mathrm{mg} / \mathrm{kg}$ body weight); $\mathrm{CMC}=$ Carboxymethyl cellulose $0.5 \%$.

Different letter for the same day showed significant difference.

H3 : DHP:AP = (p=0.01), d: (0.015); DHP:AP+ES = $(p=0.015)$

the erythrocytes by creating oxidative damage in the membrane of the cells resulting in hemolysis [20].

On D10, there was a decrease in the erythrocyte count and $\mathrm{Hb}$ level (Fig. 3), especially in the CMC and AP groups. Proteolytic activity of $\mathrm{Hb}$ in intraerythrocytes, where $\mathrm{Fe}^{2+}$ is oxidized into $\mathrm{Fe}^{3+}$, increased during the first 10 days of infection. The electron released reacts with oxygen molecule producing superoxide radicals [15]. The superoxide radicals and other oxidizing agents form methemoglobin that cannot transport oxygen [20]. This explains why there is no significant decrease in erythrocyte count and $\mathrm{Hb}$ level in the group of sambiloto combined with spirulina powder (AP+PS). C-phycocyanin, which is a water-soluble pigment of $S$. platensis, provides protection against oxidative damage to DNA plasmid protein and erythrocyte membrane. Administration of spirulina powder in a dosage of 250 and $500 \mathrm{mg} / \mathrm{kg}$ body weight for 14 days to white mice induced with cyclophosphamide can prevent a decrease in $\mathrm{Hb}$ level and erythrocyte and leukocyte counts. Seven spirulina water extract administration in the dosage of $100 \mathrm{mg} / \mathrm{kg}$

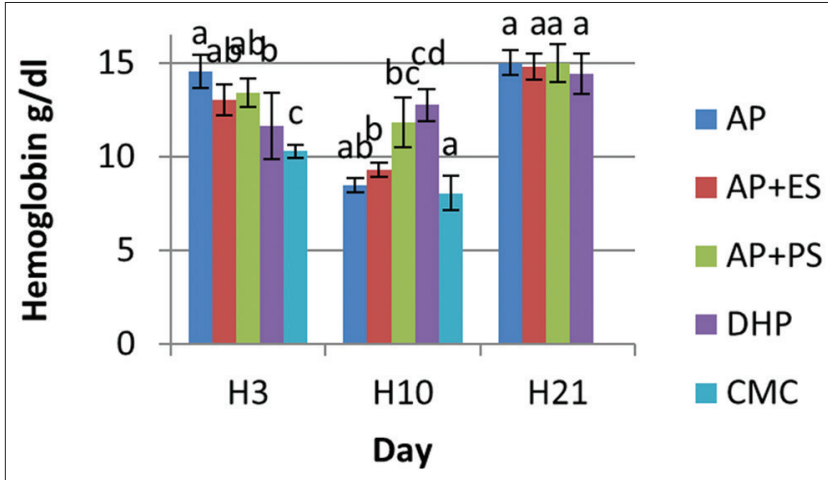

Fig. 3: Hemoglobin level (g/dl). Group: $A P=S a m b i l o t o$ $200 \mathrm{mg} / \mathrm{kg}$ body weight; AP+ES=Sambiloto $200 \mathrm{mg} / \mathrm{kg}$ body weight+spirulina extract $26 \mathrm{mg} / \mathrm{kg}$ body weight; $\mathrm{AP}+\mathrm{PS}=$ Sambiloto $200 \mathrm{mg} / \mathrm{kg}$ body weight+spirulina powder $130 \mathrm{mg} / \mathrm{kg}$ body weight; DHP=Dihydroartemisinin-piperaquine (dihydroartemisinin $15.6 \mathrm{mg}$; piperaquine $124.5 \mathrm{mg} / \mathrm{kg}$ body weight); $\mathrm{CMC}=$ Carboxymethyl cellulose $0.5 \%$. Different letter for the same day showed significant difference H10 : AP:AP+ES = (p=0.264)

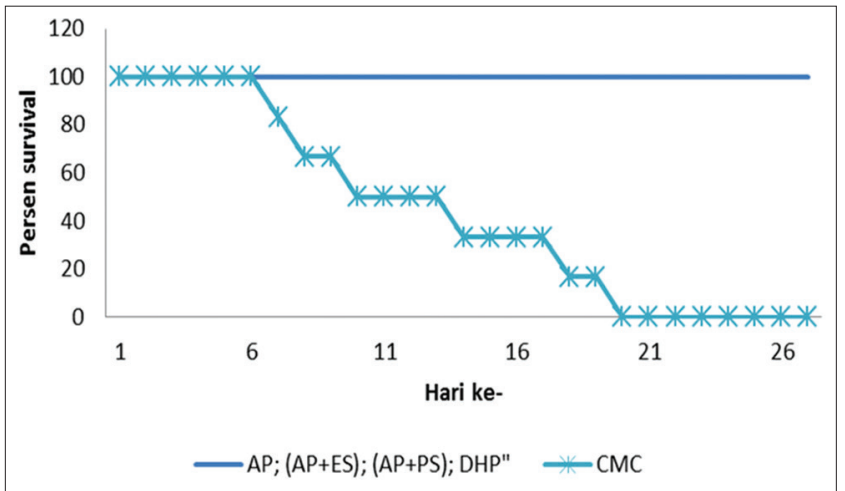

Fig. 4: Survival of experimental animals during the period of research. Group: $\mathrm{AP}=$ Sambiloto $200 \mathrm{mg} / \mathrm{kg}$ body weight; AP+ES=Sambiloto $200 \mathrm{mg} / \mathrm{kg}$ body weight+spirulina extract $26 \mathrm{mg} / \mathrm{kg}$ body weight; AP+PS=Sambiloto $200 \mathrm{mg} / \mathrm{kg}$ body weight+spirulina powder $130 \mathrm{mg} / \mathrm{kg}$ body weight; DHP=Dihydroartemisinin-piperaquine (dihydroartemisinin $15.6 \mathrm{mg}$; piperaquine $124.5 \mathrm{mg} / \mathrm{kg}$ body weight); $\mathrm{CMC}=$ Carboxymethyl cellulose $0.5 \%$

body weight to normal mice, every day for 14 days, can increase RBC, $\mathrm{Hb}$, and packed cell volume significantly compared to normal control. C-phycocyanin activity in spirulina influences the hematology profile in which c-phycocyanin stimulates erythropoietin production to induce hematopoiesis [21]

$P$. berghei infection increases the lipid peroxidation concentration in erythrocyte in the first 10 days of infection. This will make the erythrocytes to be easily damaged or experiencing hemolysis [15]. Hemolysis can also occur because of erythrocytes destruction, both infected and uninfected by the spleen reticuloendothelial system. Deformity of erythrocytes into a rigid form will result in the incapability of the erythrocytes to go through the spleen sinusoid, the erythrocytes will no longer able to escape and will be phagocytized by the macrophage. The reduction in deformability of erythrocytes is due to the failure in $\mathrm{Na}^{+} / \mathrm{K}^{+}$pump that will create intracellular $\mathrm{Na}^{+}$ion accumulation. The failure of the $\mathrm{Na}^{+} / \mathrm{K}^{+}$pump is believed to be the result of the increase in NO concentration triggered by cytokine. Dyserythropoiesis is also possible due to the role of tumor necrosis factor, interferon- $\gamma$, and interleukin in disturbing the production of erythrocytes [20]. 
There is a significant difference between the results of AP and AP+ES concerning the erythrocyte count and Hb level on D10. The erythrocyte count in the AP and AP+ES groups is significantly different $(\mathrm{p}=0.041)$, but the $\mathrm{Hb}$ level between the two groups is not significantly different $(p=0.264)$. There should be a correspondence between the erythrocyte count and $\mathrm{Hb}$ level in every group. As a reference, in this research, the erythrocyte count in normal mice was $8 \times 10^{6} / \mathrm{ml}$, whereas the $\mathrm{Hb}$ level of normal mice was $12 \mathrm{~g} / \mathrm{dl}$. The low level of $\mathrm{Hb}$ in AP+ES group is probably due to the erythrocytes in the AP+ES group contain Heinz body so that the erythrocyte count does not correspond to the Hb level. Oxidized $\mathrm{Hb}$ is marked by the presence of methemoglobin and/or Heinz body. Some of the $\mathrm{SH}$-groups of $\mathrm{Hb}$ are oxidized such that it will result in protein sedimentation in the internal of the RBCs, which subsequently will form the Heinz body. The presence of Heinz body indicates that the RBCs have already undergone oxidative stress [21]

On D21 after infection, all groups of treatments, excluding CMC, had been able to restore the erythrocyte count to the normal level. The increases in erythrocyte count and glutathione (GSH) level were observed in the sub-chronic administration of sambiloto extract. GSH is reported to prevent $\mathrm{RBC}$ from free radicals, it can, therefore, maintain the integrity of the RBC membrane [13]. In the CMC group, however, hemolysis occurred because there was little antioxidant availability. The endogen antioxidants, such as superoxide dismutase (SOD) and GSH, had already been oxidized. The increase in malondialdehyde, which is considered as an oxidative stress marker, corresponds to the decrease in the SOD and GSH levels [22].

\section{CONCLUSION}

Sambiloto extract contains saponin, flavonoid, and terpenoid, with andrographolide content of $8.30 \% \mathrm{w} / \mathrm{w}$. Spirulina extract and powder contain saponin, steroid, and flavonoid, with respective flavonoid content of $0.64 \% \mathrm{w} / \mathrm{w}$ and $0.10 \% \mathrm{w} / \mathrm{w}$, calculated as quercetin. Combination of sambiloto extract and spirulina powder (AP+PS) gave a significantly different result in suppressing the percentage of parasitemia $(p=0.02)$, increasing the erythrocyte count $(p=0.03)$, and Hb level $(p=0.01)$ at the $15^{\text {th }}$ day, compared to the group given sambiloto (AP) only.

\section{ACKNOWLEDGMENTS}

The authors are grateful to the Research and Development of Health Agency, Ministry of Health, Republic of Indonesia, for the facilities provided during the work.

\section{REFERENCES}

1. Departement Kesehatan RI. Agency for Health Research and Development, Laporan Riset Kesehatan Dasar (RISKESDAS). Jakarta: Departement Kesehatan RI; 2013.

2. Sitorus H, Salim M, Lasbudi PA. The pattern of traditional medicinal plants in Segara Kembang Village and Tungku Jaya village District of Ogan Komering Ulu. J Pembang Manus 2011;5(1):1-12.

3. Verma AK, Prasad SB, Rongpi T, Arjun J. Traditional healing with animals (zoo-therapy) by the major ethnic group of Karbi Anglong district of Assam, India. Int J Pharm Pharm Sci 2014;6(8):593-600.

4. Gohain N, Prakash A, Gogoi K, Bhattacharya DR, Nilanju P, Dahutia C, et al. An ethnobotanical survey of anti-malarial plants in some highly malaria affected districts of Assam. Int J Pharm Pharm Sci 2015;7(9):147-52

5. Zein U. Perbandingan Efikasi Ekstrak Herba Sambiloto (Andrographis paniculata Nees) Tunggal Dan Kombinasi Masing-Masing Dengan Artesunat Dan Klorokuin Pada Pasien Malaria Falsiparum Tanpa Komplikasi, Medan, Disertasi, Sekolah Pasca Sarjana, Universitas Sumatera Utara; 2009

6. Zein U, Fitri LE, Saragih A. Comparative study of antimalarial effect of sambiloto (Andrographis paniculata) extract, chloroquine and artemisinin and their combination against Plasmodium falciparum in-vitro. Acta Med Indones 2013;45(1):38-43

7. Kisdjamiatun S, Kartikawati H, Wibisono A. Effect of Andrographis paniculata herbal extract (sambiloto) on anemia and survival of Balb / c mice during infection of Plasmodium berghei Anka. Med Med Indones 2009;39(3):34-43

8. Iribhogbe OI, Agbaje EO, Oreagba IA, Aina OO, Ota AD. Antioxidant based combination therapy in malaria: In vivo study in Plasmodium berghei infected mice. Biolife 2013;1(2):70-7.

9. Dewi RS. Spirulina platensis Mencegah Penurunan Komponen Darah Perifer Pada Tikus (Rattus norvegicus) Yang Diberikan Cyclophosphamide, Tesis, Program Pasca Sarjana Biomedik, Universitas Udayana; 2014.

10. Chaiklahan R, Chirasuwan N, Loha V, Bunnag B. Lipid and fatty acid extraction from Cyanobacterium spirulina. Sci Asia 2008;34:299-305.

11. Moll K, Ljungström I, Perlmann H, Acherf A, Wahlgren M. Methods in Malaria Research, American Type Culture Collection. Manassas: University Boulevard; 2008.

12. Kusumawardhani D, Widyawaruyanti A, Kusumawati I. The antimalarial effect of standardized sambiloto extract (parameter of andrografolida content) in mice infected with P. berghei. Maj. Farmasi Airlangga 2005;5(1):25-9.

13. Gaur P. Evaluation of safety aspect of Andrographis paniculata in SwissAlbino mice at sub-acute level. Int Ayurvedic Med J 2014;2(5):681-6.

14. Murtini JT, Triwibowo R, Indriati N, Ariyani F. Uji toksisitas sub kronik Spirulina platensis secara in-vivo. J Pascapanen Bioteknol Kelaut Perikan 2010;5(2):123-33.

15. Tripathy S, Chakraborty SP, Roy S. Superoxide radical generation mediated Plasmodium berghei infection in Swiss mice. Al Ameen J Med Sci 2012;5(1):69-81.

16. Tjahjani S, Khiong K. Potential red fruit as an antioxidant against malaria berghei in Balb / C strain mice. Maj Kedokt Indones 2010;60(12):571-5.

17. Edagha IA, Atting IA, Bassey RB, Bassey EI, Ukpe SJ. Erythropoietic and hepatoprotective potential of ethanolic extract of Nuclea latifolia in mice infected with Plasmodium berghei. Am J Med Sci 2014;2(1):7-12.

18. Bukoye $\mathrm{O}$, Musbau A. Immune modulation potentials of aqueous extract of Andrographis paniculata leaves in rat. Researcher 2013;3(1):48-57.

19. Percário S, Moreira DR, Gomes BA, Ferreira ME, Gonçalves $\mathrm{AC}$, Laurindo PS, et al. Oxidative stress in malaria. Int $\mathrm{J}$ Mol Sci 2012;13(2):16346-72.

20. Elmalawany AM, Salem TA, Mohamed AH, Osman GY. Effect of blue green algae on some biochemical and hematological markers in mice. Int J Adv Res 2014;2(2):568-74.

21. Murray RK, Granner DK, Rodwell VW. Biokimia Harper. $27^{\text {nd }}$ ed. Jakarta: Penerbit Buku Kedokteran EGC; 2009.

22. Harijanto PN. Malaria, Dari Molekular ke Klinis. Jakarta: Penerbit Buku Kedokteran EGC; 2009. 